\title{
Using Digestate and Biochar as Fertilizers to Improve Processing Tomato Production Sustainability
}

\author{
Domenico Ronga ${ }^{1,2, *(\mathbb{D}}$, Federica Caradonia ${ }^{1}\left(\mathbb{D}\right.$, Mario Parisi ${ }^{3}\left(\mathbb{D}\right.$, Guido Bezzi $^{4}$, Bruno Parisi $^{5}$, \\ Giulio Allesina ${ }^{6} \mathbb{D}$, Simone Pedrazzi ${ }^{6}$ and Enrico Francia ${ }^{1} \mathbb{D}$ \\ 1 Centre BIOGEST-SITEIA, Department of Life Sciences, University of Modena and Reggio Emilia, \\ 42122 Reggio Emilia (RE), Italy; federica.caradonia@unimore.it (F.C.); enrico.francia@unimore.it (E.F.) \\ 2 CREA Research Centre for Animal Production and Aquaculture, 26900 Lodi (LO), Italy \\ 3 CREA Research Centre for Vegetable and Ornamental Crops, 84098 Pontecagnano Faiano (SA), Italy; \\ mario.parisi@crea.gov.it \\ 4 CIB-Consorzio italiano biogas e gassificazione, 26900 Lodi (LO), Italy; guido.bezzi@gmail.com \\ 5 CREA Research Centre for Cereal and Industrial Crops, 40128 Bologna (BO), Italy; bruno.parisi@crea.gov.it \\ 6 Department of Engineering 'Enzo Ferrari', University of Modena and Reggio Emilia, 41125 Modena (MO), \\ Italy; giulio.allesina@unimore.it (G.A.); simone.pedrazzi@unimore.it (S.P.) \\ * Correspondence: domenico.ronga@unimore.it; Tel.: +39-0522-522003
}

Received: 14 December 2019; Accepted: 15 January 2020; Published: 17 January 2020

check for updates

\begin{abstract}
The principal goal of the organic farming system (OFS) is to develop enterprises that are sustainable and harmonious with the environment. Unfortunately, the OFS yields fewer products per land than the non-organic farming system in many agricultural products. The objective of our study was to assess the effects of digestate and biochar fertilizers on yield and fruit quality of processing tomato produced under the OFS. The experiment was carried out in Po Valley, during the 2017 and 2018 growing seasons. Liquid digestate (LD), $\mathrm{LD}+$ biochar $(\mathrm{LD}+\mathrm{BC})$ and pelleted digestate (PD) were evaluated and compared to biochar (BC) application and unfertilized control. The results showed that plants fertilized with $\mathrm{LD}+\mathrm{BC}$ recorded the maximum marketable yield $\left(72 \mathrm{tha}^{-1}\right)$, followed by BC $\left(67 \mathrm{tha}^{-1}\right), \mathrm{PD}\left(64 \mathrm{t} \mathrm{ha}^{-1}\right)$ and $\mathrm{LD}\left(59 \mathrm{tha}^{-1}\right)$; while the lowest production $\left(47 \mathrm{tha} \mathrm{h}^{-1}\right)$ was recorded in unfertilized plants. Over the two cropping seasons, LD + BC, BC, PD, and LD, increased fruit number per plant $(+15 \%)$, fruit weight $(+24 \%)$, Brix tha ${ }^{-1}(+41 \%)$ and reduced Bostwick index $(-16 \%)$, if compared to the untreated control. Considering the overall agronomic performances, digestate and biochar can be useful options for increasing yield and quality of processing tomato production in the OFS. Hence, these fertilizers can be assessed in future research both on other crops and farming systems.
\end{abstract}

Keywords: organic farming system; yield; $\mathrm{pH}$; soluble solid content; Bostwick viscosity

\section{Introduction}

Processing tomato (Solanum lycopersicum L.) is a globally important cash crop, grown under different environments and input regimes. In 2019, worldwide production was estimated at $~ 37$ million tones [1].

In the last 20 years, agriculture challenge is to provide enough and nutritious food for the growing population, minimizing its environmental impact in order to meet the sustainable development goals [2]. The organic farming system (OFS) can be an alternative approach to improve agricultural sustainability compared to the conventional one. OFS emphasizes rotating crops, adopts animal and green manure or compost to fertilize the crops, managing abiotic and biotic stress naturally, and improving biodiversity, soil and water conservations [3]. 
Reviews and meta-analyses revealed that the OFS has greater soil carbon content and less soil erosion compared with conventional systems [4-6]. Different works also reported that the agrosystem biodiversity is improved in the OFS $[5,7,8]$. In addition, synthetic pesticides and fertilizers are not allowed, and there is a reduction of nitrate leaching and greenhouse gas emissions in comparison with the conventional farming system $[3,8,9]$. However, since the OFS has lower land-use efficiency than the conventional system, these positive effects are less pronounced and in sometime reversed when expressed per unit product $[9,10]$. Seufert et al. [11] found wheat and vegetables to be the lowest, yielding organic crops, $37 \%$ and $33 \%$ less than conventional systems, respectively. In addition, when crop production depends only on green manure crops, the crop yield might be further reduced [12]. Among vegetables processing tomato when cultivated in the OFS showed marketable yield reduction of $\sim 50 \%$ compared to conventional systems [13-17].

Cavigelli et al. [18] reported that nitrogen availability and weed control are the two main factors influencing crop yield in the OFS. Particularly, nitrogen is one of the main essential nutrients for tomato growth [19]. Scholberg et al. [20] reported that nitrogen deficiency can reduce tomato leaf area index, biomass production and fruit yield within a range from $60 \%$ to $70 \%$.

Digestate is a by-product of the anaerobic digestion coming from the biogas plant production. Digestate mainly derives from the digestion of different biomasses such as energy crops (e.g., corn silage, triticale silage, etc.), vegetable by-products and manure. The solid fraction of the digestate is rich in minerals (like nitrogen and phosphorus) and organic matter [21,22]. Therefore, digestate could be interesting as a sustainable fertilizer for crop production. Ronga et al. [23-25] suggested the use of digestate as innovative fertilizer and growing media for the production of basil, peppermint, baby leaf lettuce and grapevine in soilless cropping systems. Other researches highlighted improving in quality and yield of digestate-fertilized crops. In fact, Barzee et al. [19] reported that tomatoes fertilized with digestate had higher soluble solids contents then synthetically fertilized one, and Šimon et al. [26] reported increases in grain yield in Triticum aestivum L. to respect the untreated control.

Biochar $(\mathrm{BC})$ is considered an inorganic carbon-rich matrix obtained from organic material in the total or partial absence of oxygen at temperatures below $700{ }^{\circ} \mathrm{C}$ [27]. Biochar may enhance the growth performance and yield of crops, modifying the chemical properties of soil [28]. Changes in soil properties can make available some mineral nutrients and improve microbial activity [28]. Xu et al. [29] stated that nitrogen leaching was reduced after the application of biochar. Contradictory reports on the effectiveness of biochar on crop production are found in the literature. Indeed, squash yield was increased by biochar applications in the OFS [30], while Gonzaga et al. [31] reported that maize biomass and its nutrient uptake was not improved by the application of pinewood chip biochar. Moreover, the same authors highlighted that the increase in soil $\mathrm{pH}$ may result in potentially greater nitrogen losses than unfertilized control. Finally, Hol et al. [32] suggested that biota from biochar-amended soil was less beneficial for legume plant growth and flowering was delayed.

Few pieces of research are focused on the use of digestate and biochar in the OFS and no one has yet assessed the effectiveness of these two products applied together in the OFS. In light of the revision of the European organic regulation (CE 889/2008) that in addition to the recent inclusion of the digestate could allow also the use of biochar as fertilizers, is fundamental to provide useful information both to farmers and policymakers. Hence, the objective of the present study was to assess the effectiveness of different digestate fertilizers, biochar, and digestate + biochar on yield and fruit technological characteristics ( $\mathrm{pH}$, soluble solid contents, Bostwick viscosity) of processing tomato under the OFS.

\section{Materials and Methods}

\subsection{Field Experiments}

The trial was carried out, during a two-year period (2017-2018), in an organic farm located in Po Valley $\left(44^{\circ} 41^{\prime} 17.9^{\prime \prime} \mathrm{N} ; 10^{\circ} 34^{\prime} 00.2^{\prime \prime} \mathrm{E}\right.$ and altitude of $65 \mathrm{~m}$ a.s.l., Reggio Emilia, Italy), however on two 
different fields to follow the traditional crop rotation used by the farmer. The well-drained soil was classified as Alfisoil, according to the American classification of Soil Taxonomy [33]. Sampling up to 30 $\mathrm{cm}$ depth was done one month before the transplanting and were immediately analyzed for the main physical and chemical properties, reported in Table 1.

Table 1. Physical and chemical soil properties of two-year experiment. EC = electrical conductivity; $\mathrm{TN}=$ total nitrogen; $\mathrm{CEC}=$ cation exchange capacity.

\begin{tabular}{|c|c|c|}
\hline Soil Characteristics & 2017 & 2018 \\
\hline Sand (\%) & 5.8 & 11.2 \\
\hline Silt (\%) & 54.1 & 67.5 \\
\hline Clay (\%) & 40.1 & 21.3 \\
\hline $\begin{array}{c}\mathrm{pH}(-) \\
\text { (Soil water suspension) }\end{array}$ & 7.2 & 7.8 \\
\hline $\begin{array}{c}\mathrm{EC}\left(\mathrm{dS} \mathrm{m}^{-1}\right) \\
\text { (1:5 soil-to-water) }\end{array}$ & 0.1 & 0.2 \\
\hline $\mathrm{CaCO} 3$ eq (\%) & 2.8 & 9.4 \\
\hline $\begin{array}{l}\text { Exchangeable } \mathrm{K}_{2} \mathrm{O}\left(\mathrm{mg} \mathrm{kg}^{-1} \text { ) }\right. \\
\text { (Ammonium acetate method) }\end{array}$ & 226.1 & 179.9 \\
\hline $\begin{array}{l}\text { Available } \mathrm{P}_{2} \mathrm{O}_{5}\left(\mathrm{mg} \mathrm{kg}^{-1}\right) \\
\text { (Olsen method) }\end{array}$ & 34.4 & 55.0 \\
\hline $\begin{array}{c}\text { TN (\%o) } \\
\text { (Kjeldahl method) }\end{array}$ & 1.5 & 1.3 \\
\hline Organic matter (\%) & 2.3 & 1.8 \\
\hline CEC (meq $\left.100 \mathrm{~g}^{-1}\right)$ & 27.0 & 17.9 \\
\hline
\end{tabular}

The climate is typical continental with cold winter and dry and warm summer. The mean maximum and minimum air temperatures and total rainfall recorded during the cropping cycles (May to September) were $29.6^{\circ} \mathrm{C}, 18.1^{\circ} \mathrm{C}$ and $191.4 \mathrm{~mm}$ in 2017 , and $28.8^{\circ} \mathrm{C}, 18.7^{\circ} \mathrm{C}$ and $279.2 \mathrm{~mm}$, in 2018 , respectively (Figure 1).

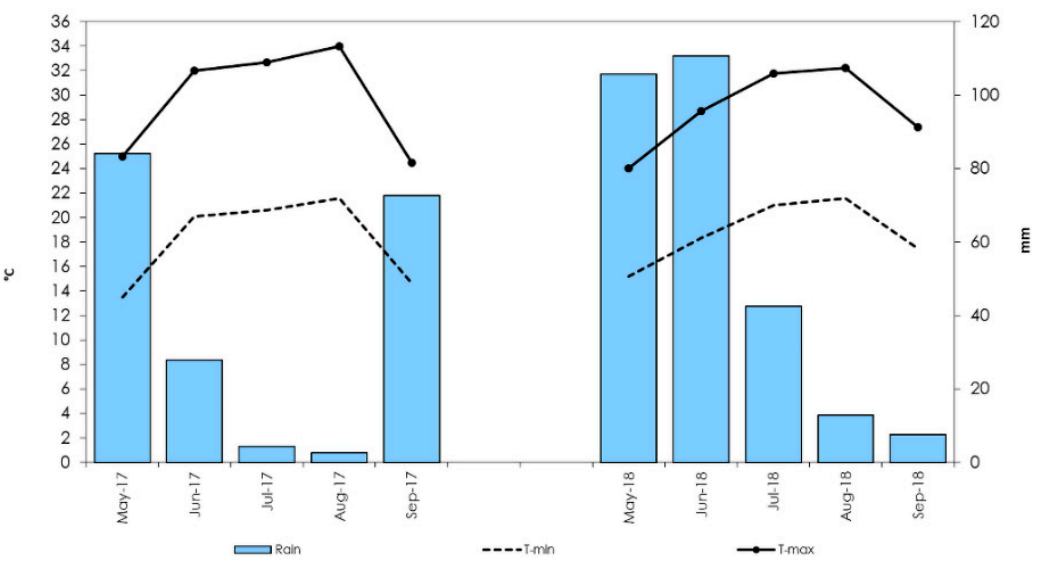

Figure 1. The mean maximum and minimum air temperatures and total rainfall recorded during the cropping cycles (May to September) in the two growing seasons (2017 and 2018).

The OFS comprising the two-year experiment provided for the following crop rotation: alfalfa (four years) - bread wheat (one crop cycle)_autumn-cover crop of Vicia faba L. and Sinapis arvensis (half and half mixture, one crop cycle)—processing tomato. The cover crop was used as green manure for the processing tomato production.

\subsection{Growth Condition}

In both years, tomato seedlings (Barone Rosso cultivar with blocky-shaped fruits provided by Tomato Colors, Bologna, Italy) were transplanted into the open field within the first week of May at 2.8 
plants $\mathrm{m}^{-2}$ in a single row with a spacing of $1.60 \mathrm{~m}$ between each row and $0.22 \mathrm{~m}$ between plants in the row. This plant density and row spacing were typical for processing tomato cultivation in Northern Italy and were suitable for mechanical harvesting.

Three digestate fertilizers [liquid digestate (LD), liquid digestate + biochar (LD + BC) and pelleted digestate (PD)] were assessed in comparison with biochar $(\mathrm{BC})$ application and unfertilized plants (null control). For treatment LD + BC, LD and BC were applied together using half rates of the dose adopted for $\mathrm{LD}$ and $\mathrm{BC}$ treatment, respectively.

A randomized complete block design with three replications was adopted and each plot measured $32 \mathrm{~m}^{-2}(6.4 \mathrm{~m} \times 5.0 \mathrm{~m})$.

The amounts of different fertilizers [ $\mathrm{LD},(\mathrm{LD}+\mathrm{BC}), \mathrm{BC}$ and $\mathrm{PD}]$ applied were calculated considering a total of $150 \mathrm{~kg} \mathrm{ha}^{-1}$ of $\mathrm{N}$ to supply for a tomato crop cycle. The control (CTRL) was untreated. All the tested fertilizers were manually applied (on the row afterward used to transplant seedlings) and buried using a disc harrow (one week before the manual transplant).

For irrigation scheduling, evapotranspiration of the crop (ETc) was calculated as ETc $=\mathrm{ETo} \times \mathrm{Kc}$, where ETo (reference evapotranspiration) was determined according to Hargreaves and Samani [34], and $\mathrm{Kc}$ (crop coefficient) for tomato crop was adjusted for the environmental conditions and crop growth stage [35]. In each plot, $100 \%$ ETc was restored when $40 \%$ of the total available water was depleted, according to the evapotranspiration method of Doorenbos and Pruitt [36]. A total of 351.0 $\mathrm{mm}$ and $224.4 \mathrm{~mm}$ of irrigation water were applied in 2017 and 2018, respectively, by drip irrigation.

Weeds control and plant protection were done according to the OFS cultivation guidelines of the Emilia-Romagna Region (Italy). A single harvest was carried out at the end of the growing seasons in each year, i.e., within the first ten days of September 2017 and 2018, when the ripe fruits accounting for approximately $85 \%$ of the total.

\subsection{Digestate Fertilizers and Biochar Productions}

Digestate and pellets were produced in an anaerobic digester (AD) plant owned by CAT-Cooperativa Agroenergetica Territoriale (Correggio, Reggio Emilia, Italy) as described by Pulvirenti et al. [21]. The raw materials (ingestates) used in AD were maize (Zea mais L.) silage $(43 \%)$, triticale (X Triticosecale Wittmack) silage (22\%), cow slurry $(27 \%)$, and grape stalks (of Vitis vinifera L.) (8\%). Ingestate proportions were calculated according to their fresh weight [21]. After solid/liquid separation (using a dewatering machine) of the fresh digestate, the chemical parameters (on fresh weight basis) of the liquid phase were the following: total carbon (TC, 4.45\%), total organic carbon (TOC, $3.74 \%$ ), total nitrogen $\left(\mathrm{TN}, 0.34 \%\right.$ ), potassium $\left(\mathrm{K}_{2} \mathrm{O}, 0.95 \%\right)$, (phosphorous as $\mathrm{P}_{2} \mathrm{O}_{5}$, was completely absent). Electrical conductivity $\left(\mathrm{EC}=1.07 \mathrm{dS} \mathrm{m}^{-1}\right)$ and $\mathrm{pH}(8.03)$ were measured on wet material (1:5 ratio), using a pH-conductivity meter (FiveEasy ${ }^{\mathrm{TM}}$ model, Mettler Toledo, Giessen, Germany). Conversely, solid-phase digestate was dried and pelleted accordingly to the description of Pulvirenti and collaborators [21]. This pellet (PD) was also analyzed and the results (expressed on a fresh weight basis) were here reported (TC $17.19 \%$, TOC 16.32\%, TN 1.5\%, $\mathrm{P}_{2} \mathrm{O}_{5} 2.5 \%, \mathrm{~K}_{2} \mathrm{O} 2.0 \%$, EC $4.17 \mathrm{dS} \mathrm{m}^{-1}$, and $\mathrm{pH} 8.28$ ).

The BC used, in our work, was produced as described by Ronga et al. [25], except that pine wood chips were used as feedstock in the gasifier (PP20 gasifier, manufactured by ALL Power Labs, Berkeley, $\mathrm{CA}, \mathrm{USA})$. The obtained $\mathrm{BC}$ displayed the following chemical characteristics: total inorganic carbon (TIC, $73.4 \%$ ), TN $0.37 \%, \mathrm{~K}_{2} \mathrm{O} 3.75 \%$, EC $2.57 \mathrm{dS} \mathrm{m}^{-1}$, and $\mathrm{pH} 10.1$.

\subsection{Recorded Parameters on Tomato Crops}

At harvest time, five plants were sampled, and plant height was measured. Moreover, physiological parameters were detected on the youngest fully expanded leaf, using the portable Dualex 4 Scientific (FORCEA, Orsay, France) instrument: chlorophyll (CHL), flavonoid (FLAV), and anthocyanin (ANTH) contents were estimated. Finally, the nitrogen balance index (NBI) was calculated as the ratio between CHL and FLAV parameters. 
At canopy level, Normalized Difference Vegetation Index (NDVI) was measured by SRS-NDVI (Decagon Device, Pullman, WA, USA), while, the photochemical reflectance index (PRI) were detected using Decagon SRS-PRI (Decagon Device, Pullman, WA, USA) instrument. The measurements of this physiological index were taken at a distance of $1 \mathrm{~m}$ above the canopy. Ten average spectra, each a mean of 10 spectra, were recorded per plot.

In order to compare $\mathrm{N}$ use across the treatments, the nitrogen applied efficiency (NAE) index was calculated, which was derived from the marketable fruit yield $\left(\mathrm{t} \mathrm{ha}^{-1}\right)$ and the amount of $\mathrm{N}$ applied $\left(\mathrm{kg} \mathrm{ha}^{-1}\right)$ and expressed as t yield $\mathrm{kg}^{-1} \mathrm{~N}$ [37].

Fruit water productivity (FWP) was also calculated as the ratio between the marketable yield (kg) and the total water used by plants ( $\mathrm{mm}$ ) during the growing season [38].

For destructive measurements, five plants were measured for the main stem length and then harvested dividing the fruits in ripe, unripe and affected by blossom-end rot (BER). Collected berries were counted and weighed, so total and marketable yield, and mean fruit weight were calculated. The above ground biomass was weighed, recorded and oven-dried at $65^{\circ} \mathrm{C}$ until constant weight and total biomass dry weight was obtained.

For fruit quality, $\sim 35$ collected fruits per each harvest plot were ground and homogenized (under cold break preparation) and different parameters were then assessed. The $\mathrm{pH}$ was measured with a Basic $20 \mathrm{pH}-$ meter (Crison, Instrument, Barcelona, Spain), while ${ }^{\circ}$ Brix was determined using a digital refractometer (HI 96814, Hanna Instruments, Villafranca Padovana, Italy). Brix t ha ${ }^{-1}$ was calculated by multiplying the marketable yield $\left(\mathrm{t} \mathrm{ha}^{-1}\right)$ by ${ }^{\circ}$ Brix and dividing the result by 100 . Finally, Bostwick test was carried out according to that described by Ranganna [39] and viscosity was expressed as distance $(\mathrm{cm})$ a sample flows in each time interval $(1 \mathrm{~min})$. The experiment was performed at room temperature and repeated three times.

\subsection{Data Analysis}

Agronomic and physiological data were subjected to analysis of variance (one-way ANOVA) separately per each growing season due to unpredictable weather conditions under the Mediterranean basin [40]. Means were separated, when the ' $F$ ' test of ANOVA for treatment was significant at least at the 0.05 probability level. For statistical analysis GENSTAT 17th software package (VSN International, Hemel Hempstead, UK) was used.

\section{Results}

Three digestate fertilizers (LD, LD + BC and PD) were assessed and compared with biochar application and unfertilized plants (CTRL). In both years of the trial all fertilizers increased marketable yield respect to CTRL; moreover, the highest values resulted under LD + BC applications $(+54 \%$ and $+51 \%$, respect to the CTRL, in 2017 and 2018, respectively) (Table 2). A similar trend was also recorded for total yield in both years, with LD + BC treatment that also displayed the highest values $(+36 \%$ and $+47 \%$, respect to the CTRL, in 2017 and 2018, respectively). In addition, our results revealed that LD $+\mathrm{BC}, \mathrm{BC}, \mathrm{PD}$ and LD, significantly increased fruit number per plant compared to unfertilized plots in both the investigated years. Among treatments LD + BC displayed the highest values, and across years an average increment of $+16 \%$ compared to the unfertilized plant was found. In addition, $L D$ and $B C$ when separately applied, resulted in a significantly lower number of fruits per plant than LD + $\mathrm{BC}$ combination.

The fertilizers assessed in the present study also affected plant morphological parameters in both cropping seasons. Significant lower values of plant height were found for LD + BC thesis in both years (34 cm and $31 \mathrm{~cm}$, in 2017 and 2018, respectively). However, in the second year, plant height under untreated control did not differ from LD + BC. 
Table 2. Effect of different digestate and biochar fertilizers on yield and its components. $C T R L=$ unfertilized plants; $B C=$ biochar; $L D=$ liquid digestate; $L D+B C=$ liquid digestate + biochar; PD = pelleted digestate. Different letters within each column and year indicate significant differences according to Duncan's test ( $p \leq 0.05)$.

\begin{tabular}{|c|c|c|c|c|c|c|c|c|c|c|c|c|c|c|}
\hline TREATMENT & $\begin{array}{l}\text { Total Yield } \\
\left(\mathrm{t} \mathrm{ha}^{-1}\right)\end{array}$ & & $\begin{array}{l}\text { Marketable } \\
\left.\text { Yield (t ha }{ }^{-1}\right)\end{array}$ & & $\begin{array}{c}\text { Fruit } \\
\text { Number (no. } \\
\text { plant }^{-1} \text { ) }\end{array}$ & & $\begin{array}{c}\text { Plant } \\
\text { Height }(\mathrm{cm})\end{array}$ & & $\begin{array}{l}\text { Main Stem } \\
\text { Lenght }(\mathrm{cm})\end{array}$ & & $\begin{array}{l}\text { Aboveground } \\
\text { Fresh Weight } \\
\left.\text { (g plant }^{-1}\right)\end{array}$ & & $\begin{array}{c}\text { Aboveground } \\
\text { Dry Weight } \\
\left.\text { (g plant }^{-1}\right)\end{array}$ & \\
\hline \multicolumn{15}{|l|}{ YEAR 2017} \\
\hline CTRL & 52.1 & $\mathrm{~d}$ & 45.2 & $\mathrm{e}$ & 24.7 & $\mathrm{~d}$ & 43.0 & $\mathrm{~b}$ & 69.0 & $\mathrm{e}$ & 667.0 & $\mathrm{~d}$ & 22.6 & c \\
\hline $\mathrm{BC}$ & 66.2 & c & 64.2 & $\mathrm{~b}$ & 27.8 & $\mathrm{~b}$ & 51.0 & $\mathrm{a}$ & 75.0 & $\mathrm{~d}$ & 1114.0 & $\mathrm{bc}$ & 25.8 & $\mathrm{~b}$ \\
\hline LD & 71.1 & $\mathrm{~b}$ & 57.0 & $\mathrm{~d}$ & 26.1 & c & 50.0 & $\mathrm{a}$ & 86.0 & $\mathrm{~b}$ & 994.0 & c & 23.3 & c \\
\hline $\mathrm{LD}+\mathrm{BC}$ & 77.6 & $\mathrm{a}$ & 69.6 & $\mathrm{a}$ & 28.8 & $\mathrm{a}$ & 34.0 & c & 95.0 & $\mathrm{a}$ & 1294.0 & $\mathrm{a}$ & 29.8 & a \\
\hline PD & 70.7 & $\mathrm{~b}$ & 61.4 & c & 27.7 & $\mathrm{~b}$ & 51.0 & $\mathrm{a}$ & 80.0 & c & 1234.0 & $a b$ & 23.1 & $\mathrm{c}$ \\
\hline \multicolumn{15}{|l|}{ YEAR 2018} \\
\hline CTRL & 54.6 & c & 49.5 & $\mathrm{e}$ & 25.3 & d & 32.0 & c & 70.0 & bc & 538.0 & c & 22.2 & c \\
\hline $\mathrm{BC}$ & 71.0 & $\mathrm{~b}$ & 69.6 & $\mathrm{~b}$ & 28.4 & $\mathrm{~b}$ & 40.0 & $\mathrm{~b}$ & 69.0 & c & 914.0 & $a b$ & 19.7 & $\mathrm{e}$ \\
\hline LD & 71.7 & $\mathrm{~b}$ & 61.2 & $\mathrm{~d}$ & 25.9 & c & 39.0 & $\mathrm{~b}$ & 72.0 & $\mathrm{~b}$ & 821.0 & $\mathrm{~b}$ & 21.5 & $\mathrm{~d}$ \\
\hline $\mathrm{LD}+\mathrm{BC}$ & 80.1 & a & 74.5 & a & 29.2 & a & 31.0 & c & 94.0 & $\mathrm{a}$ & 1034.0 & $\mathrm{a}$ & 25.5 & a \\
\hline PD & 73.1 & $\mathrm{~b}$ & 66.8 & c & 28.2 & $\mathrm{~b}$ & 50.0 & $\mathrm{a}$ & 70.0 & $\mathrm{bc}$ & 991.0 & $\mathrm{a}$ & 23.2 & $\mathrm{~b}$ \\
\hline
\end{tabular}


More consistent differences for the main stem length as effect of different treatments were noticed in the first year of the experiment than the second one. However, the LD + BC application always resulted in the highest values of main stem length $(95 \mathrm{~cm}$ and $94 \mathrm{~cm}$, in the 2017 and 2018, respectively) that significantly differed by unfertilized and fertilized thesis.

For the aboveground biomass fresh weight, the highest values were found for $\mathrm{LD}+\mathrm{BC}$ treatment that did not significantly differ from PD (1294 and $1234 \mathrm{~g}$ per plant, respectively) in 2017 and from PD and BC fertilizers (1034, 991 and $914 \mathrm{~g}$ per plant, respectively) in 2018.

$\mathrm{LD}+\mathrm{BC}$ fertilization also increased the aboveground biomass dry weight respect to the control both in 2017 (29.8 and $22.6 \mathrm{~g}$ per plant, respectively) and in 2018 ( 25.5 and $22.2 \mathrm{~g}$ per plant, respectively).

Considering the parameters related to tomato crop physiology (Table 3), all of them were statistically affected by fertilizer treatments. For the leaf measurements, our research highlighted that LD displayed the highest values of leaf chlorophyll content (CHL) $(+19 \%$ and $+9 \%$, respect to the CTRL, in 2017 and 2018, respectively). Flavonoid contents measured in 2017 ranged from the lowest value of 2.22 for LD to the highest one of 2.83 for CTRL, and the same trend was observed in 2018 with the lowest value detected in LD-fertilized plants (2.27), while CTRL confirmed the highest flavonoid contents (3.29). For leaf anthocyanin content (ANTH), PD fertilizer resulted in the highest amounts of these metabolites in both years, without significant differences from BC treatment in 2017. For the nitrogen balance index (NBI) values, as ratio between CHL and FLAV, the highest values were recorded by LD treatment in both years (19.1 and 15.8, for 2017 and 2018 respectively); moreover, for this parameter increases of $+52 \%$ and $+56 \%$ (in 2017 and 2018, respectively) were detected comparing LD fertilizer with CTRL. Regarding measurements on the canopy, in both years the lowest values of NDVI were noticed, when LD + BC fertilizer was applied (0.54 and 0.53 in 2017 and 2018, respectively). Conversely, LD treatment and CTRL showed the highest values of NDVI, in the first and second years of the experiment, respectively. Considering the photochemical reflectance index (PRI), the highest values were displayed by BC treatment ( $+16 \%$ and $+49 \%$ than the CTRL, in 2017 and 2018, respectively), while the lowest values resulted adopting $\mathrm{LD}+\mathrm{BC}$ combination in both cropping seasons.

For fruit water productivity (FWP) and nitrogen applied efficiency (NAE), LD + BC displayed higher values than the other treatments, with average values of $+25 \%$ and $+13 \%$ (across treatments and years), respectively.

Regarding the effect of treatments on tomato fruit quality all the fertilizers significantly increased mean fruit weight ( $+24 \%$ across treatments and years) and the number of fruits affected by blossom-end rot (BER) per plant compared to the unfertilized plants (CTRL) (Table 4).

In both investigated years, LD induced the highest ${ }^{\circ}$ Brix values $(+11 \%$ and $+13 \%$, respect to the CTRL, in 2017 and 2018, respectively), while Brix $\mathrm{t} \mathrm{ha}^{-1}$ was positively affected by LD + BC application in both years $(+52 \%$ and $+48 \%$, respect to the CTRL, in 2017 and 2018, respectively). However, no significant differences were found between $L D+B C$ combination and BC fertilizer in 2017. Other technological parameters of fresh fruit were also affected by fertilizers in comparison to untreated plants (CTRL). Indeed, $\mathrm{LD}+\mathrm{BC}$ significantly increased $\mathrm{pH}(+10 \%$ and $7 \%$, respect to the CTRL, in 2017 and 2018, respectively), and, on average, all fertilizers decreased the Bostwick index ( -16\% respect to the CTRL, across treatments and years), hence increasing the juice consistency. 
Table 3. Effect of different digestate and biochar fertilizers on physiological parameters. CTRL $=$ unfertilized plants; $B C=$ biochar; $L D=$ liquid digestate; $\mathrm{LD}+\mathrm{BC}=$ liquid digestate + biochar; $\mathrm{PT}=$ pelleted digestate; $\mathrm{CHL}=$ leaf chlorophyll content index; FLAV = leaf flavonoid contents index; $\mathrm{ANTH}=$ leaf anthocyanin contents index; NBI = nitrogen balance index (CHL/FLAV ratio); NDVI = normalized difference vegetation index; PRI = photochemical reflectance index; FWP = fruit water productivity; NAE = nitrogen applied efficiency; $\mathrm{x}=$ measured using Dualex 4 Scientific; $\mathrm{y}=$ using instrument SRS-NDVI; $\mathrm{z}=$ using instrument SRS-PRI. Different letters within each column and year indicate significant differences according to Duncan's test $(p \leq 0.05)$.

\begin{tabular}{|c|c|c|c|c|c|c|c|c|c|c|c|c|c|c|c|c|}
\hline TREATMENT & $\mathrm{CHL}_{\mathrm{x}}(-)$ & & $\operatorname{FLAV}_{x}(-)$ & & $\operatorname{ANTH}_{x}(-)$ & & $\mathrm{NBI}_{x}(-)$ & & $\operatorname{NDVI}_{\mathbf{y}}(-)$ & & $\mathrm{PRI}_{z}(-)$ & & FWP (kg mm $\left.{ }^{-1}\right)$ & & NAE $\left(t^{~ k g}{ }^{-1}\right)$ & \\
\hline \multicolumn{17}{|l|}{ YEAR 2017} \\
\hline CTRL & 35.64 & $\mathrm{~b}$ & 2.83 & a & 0.272 & $\mathrm{c}$ & 12.6 & $\mathrm{~b}$ & 0.74 & $\mathrm{~b}$ & -0.005 & $\mathrm{~b}$ & 0.0029 & $\mathrm{~d}$ & - & \\
\hline $\mathrm{BC}$ & 24.13 & $\mathrm{~d}$ & 2.47 & c & 0.406 & $\mathrm{a}$ & 9.8 & $\mathrm{~d}$ & 0.73 & c & 0.001 & $\mathrm{a}$ & 0.0042 & $\mathrm{~b}$ & 0.428 & $\mathrm{~b}$ \\
\hline LD & 42.36 & $\mathrm{a}$ & 2.22 & $\mathrm{~d}$ & 0.203 & $\mathrm{~d}$ & 19.1 & $\mathrm{a}$ & 0.80 & $\mathrm{a}$ & -0.041 & $\mathrm{~d}$ & 0.0038 & $\mathrm{c}$ & 0.380 & d \\
\hline $\mathrm{LD}+\mathrm{BC}$ & 30.61 & c & 2.71 & $\mathrm{~b}$ & 0.382 & $\mathrm{~b}$ & 11.3 & c & 0.54 & $\mathrm{e}$ & -0.289 & e & 0.0046 & $\mathrm{a}$ & 0.464 & $\mathrm{a}$ \\
\hline PD & 23.01 & $\mathrm{e}$ & 2.75 & $\mathrm{~b}$ & 0.408 & $\mathrm{a}$ & 8.4 & $\mathrm{e}$ & 0.68 & $\mathrm{~d}$ & -0.036 & c & 0.0040 & $\mathrm{~b}$ & 0.410 & $\mathrm{c}$ \\
\hline \multicolumn{17}{|l|}{ YEAR 2018} \\
\hline CTRL & 32.80 & $\mathrm{~b}$ & 3.29 & $\mathrm{a}$ & 0.334 & $\mathrm{~d}$ & 10.1 & $\mathrm{~b}$ & 0.79 & $\mathrm{a}$ & -0.067 & $\mathrm{~d}$ & 0.0035 & $\mathrm{~d}$ & - & \\
\hline $\mathrm{BC}$ & 22.41 & $\mathrm{~d}$ & 3.04 & $\mathrm{~b}$ & 0.254 & $\mathrm{e}$ & 7.4 & d & 0.68 & $\mathrm{~d}$ & -0.033 & a & 0.0049 & $\mathrm{~b}$ & 0.464 & $\mathrm{~b}$ \\
\hline LD & 35.74 & $\mathrm{a}$ & 2.27 & $\mathrm{e}$ & 0.479 & $\mathrm{~b}$ & 15.8 & $\mathrm{a}$ & 0.73 & $\mathrm{~b}$ & -0.036 & $\mathrm{~b}$ & 0.0043 & $\mathrm{c}$ & 0.408 & $\mathrm{~d}$ \\
\hline $\mathrm{LD}+\mathrm{BC}$ & 29.80 & c & 2.69 & $\mathrm{c}$ & 0.372 & c & 11.1 & $\mathrm{c}$ & 0.53 & $\mathrm{e}$ & -0.288 & $\mathrm{e}$ & 0.0053 & $\mathrm{a}$ & 0.497 & $\mathrm{a}$ \\
\hline PD & 15.66 & e & 2.34 & $\mathrm{~d}$ & 0.488 & $\mathrm{a}$ & 6.7 & $\mathrm{~d}$ & 0.71 & c & -0.048 & c & 0.0047 & $\mathrm{~b}$ & 0.445 & c \\
\hline
\end{tabular}

Table 4. Effect of different digestate and biochar fertilizers on fruit quality parameters. CTRL $=$ unfertilized plants; $B C=$ biochar; $L D=$ liquid digestate used as fertilizer; $\mathrm{LD}+\mathrm{BC}=$ liquid digestate + biochar; $\mathrm{PD}=$ pelleted digestate; $\mathrm{BER}=$ blossom-end rot. Different letters within each column indicate significant differences according to Duncan's test $(p \leq 0.05)$.

\begin{tabular}{|c|c|c|c|c|c|c|c|c|c|c|c|c|}
\hline TREATMENT & $\begin{array}{l}\text { Mean Fruit } \\
\text { Weight (g) }\end{array}$ & & $\begin{array}{l}\text { Fruit Affected by } \\
\text { BER (no. plant }{ }^{-1} \text { ) }\end{array}$ & & ${ }^{\circ}$ Brix & & $\begin{array}{c}\text { Brix Yield (t } \\
\text { ha }^{-1} \text { ) }\end{array}$ & & $\mathrm{pH}$ & & $\begin{array}{c}\text { Bostwick (cm } \\
\left.30 \mathrm{~s}^{-1}\right)\end{array}$ & \\
\hline \multicolumn{13}{|l|}{ YEAR 2017} \\
\hline CTRL & 65.33 & $\mathrm{~d}$ & 7.0 & $\mathrm{~d}$ & 6.1 & $\mathrm{c}$ & 2.75 & $\mathrm{~d}$ & 4.32 & $\mathrm{~d}$ & 5.5 & $\mathrm{a}$ \\
\hline $\mathrm{BC}$ & 82.67 & $\mathrm{~b}$ & 10.0 & $\mathrm{c}$ & 6.5 & $\mathrm{~b}$ & 4.18 & $\mathrm{a}$ & 4.51 & $\mathrm{~b}$ & 5.0 & $\mathrm{~b}$ \\
\hline LD & 78.00 & c & 43.0 & $\mathrm{a}$ & 6.8 & $\mathrm{a}$ & 3.87 & $\mathrm{~b}$ & 4.30 & d & 4.5 & $\mathrm{c}$ \\
\hline $\mathrm{LD}+\mathrm{BC}$ & 86.30 & $\mathrm{a}$ & 15.0 & $\mathrm{~b}$ & 6.0 & c & 4.18 & $\mathrm{a}$ & 4.74 & a & 4.0 & $\mathrm{~d}$ \\
\hline PD & 79.33 & c & 11.0 & c & 5.7 & $\mathrm{~d}$ & 3.51 & c & 4.45 & c & 5.0 & $\mathrm{~b}$ \\
\hline \multicolumn{13}{|l|}{ YEAR 2018} \\
\hline CTRL & 70.00 & $\mathrm{~d}$ & 8.0 & $\mathrm{e}$ & 6.0 & $\mathrm{bc}$ & 2.97 & $\mathrm{~d}$ & 4.27 & c & 5.5 & $\mathrm{a}$ \\
\hline $\mathrm{BC}$ & 87.50 & $\mathrm{~b}$ & 20.0 & $\mathrm{~b}$ & 6.1 & $\mathrm{~b}$ & 4.24 & $\mathrm{~b}$ & 4.46 & $\mathrm{~b}$ & 4.5 & c \\
\hline LD & 84.30 & c & 39.0 & a & 6.8 & $\mathrm{a}$ & 4.16 & $\mathrm{~b}$ & 4.29 & c & 4.5 & $\mathrm{c}$ \\
\hline $\mathrm{LD}+\mathrm{BC}$ & 91.10 & $\mathrm{a}$ & 13.0 & c & 5.9 & $\mathrm{~cd}$ & 4.40 & $\mathrm{a}$ & 4.55 & a & 4.5 & $\mathrm{c}$ \\
\hline PD & 84.70 & c & 11.0 & d & 5.8 & $\mathrm{~d}$ & 3.87 & $\mathrm{c}$ & 4.41 & $\mathrm{~b}$ & 5.0 & $\mathrm{~b}$ \\
\hline
\end{tabular}




\section{Discussion}

High marketable yield is the most important goal in processing tomato production [41]; however, a large amount of external inputs is required [42]. Processing tomato sustainability may be increased by adopting the OFS [43] and recently consumers are increasing the purchase of organic farming products [44]. However, as reported by Ronga et al. [13], lower marketable yields have been reported in tomato crops cultivated in Southern Italy under the OFS in comparison to conventional farming systems. Hence, it is of paramount importance for the OFS, that innovative agronomic strategy can be identified to reduce the current gap with the conventional farming system. In our work digestate coming from biogas plant and pinewood chip biochar were assessed as alternative fertilizers studying their effects on processing tomato physiology, yield and fruit quality.

In our study marketable yield was positively affected by different fertilizations showing an average of $66 \mathrm{t} \mathrm{ha}^{-1}$ across the thesis-furthermore, $\mathrm{LD}+\mathrm{BC}$ combination resulted in the highest productivity in both years (2017-2018).

Comparisons with other studies on processing tomato produced under the OFS seems not to be easy in relation to the different environments, cultivars, and agronomic management adopted in other studies. Nonetheless, the marketable yield recorded in our research falls into the range reported by Ronga et al. [45,46], showing an average of $45 \mathrm{tha}^{-1}$ and $86 \mathrm{tha}^{-1}$ in Italian and Californian experiments, respectively.

Considering that the average marketable yield recorded under a conventional farming system in Italy in the last two years was $\sim 50 \mathrm{t} \mathrm{ha}^{-1}$ [47], our results demonstrated that it is possible to reduce the production gap between the OFS and traditional management in processing tomato production. However, the average yield reported under conventional systems, considered both specialized and not specialized farms in processing tomato production, but also fields irrigated with different water distribution systems. Indeed, in the same area, where the present study was carried out and especially in specialized farms, processing tomato crops grown under the conventional system reached productions of $\sim 100 \mathrm{t} \mathrm{ha}^{-1}$ [48].

The highest marketable yield displayed by LD + BC fertilization can be related to seven main parameters: fruit number per plant, fruit weight, plant height, main stem length, aboveground biomass production, FWP and NAE, according to the results showed by Barrios-Masias and Jackson [49] and, Ronga et al. [48], which investigated the main morphological and physiological parameter involved in increasing marketable yield under different environments (California and Italy, respectively).

Fruit number per plant and fruit weight are the two most important parameters contributing in tomato yield. Gains achieved in marketable yield for processing tomatoes were mainly ascribed to an increase in fruit number per plant [50], nevertheless, Hihashide and Heuvelink [51] reported the importance of fruit weight in increasing gains in fresh tomatoes for greenhouse productions. The highest values of fruit number per plant and fruit weight found using LD + BC fertilizer can be due to an increase in water (rainfall and irrigation) and nutrient (carrying by LD) retentions in the soil as effect of biochar administration, as already reported by Laird et al. [52] and Sun and Lu [53]. Furthermore, Scaglia et al. [54] reported that digestates, coming from the biogas plants, can contain phytohormones as well as other bioactive compounds able to improve plant growth. Nitrogen availability, different potassium, phosphorous and bioactive compounds contents of fertilizers investigated in our study, as well as the capacity of biochar to increase the nutrient retentions supplied by LD fertilization represent critical aspects to be investigated in a future study in order to explain the results obtained here.

Barrios-Masias et al. [49] reported a positive correlation between tomato yield and leaf photosynthetic activity and the same physiological behavior was also reported for other crops like wheat [55]. NBI, calculated as the ratio between chlorophyll and polyphenols leaf contents, is an index of the crop nitrogen status [56]. The highest values of NBI and leaf chlorophyll content showed by LD-fertilized plants, in both growing seasons, can suggest a low nitrogen utilization for increasing fruit production. This hypothesis was also confirmed by the lowest value of NAE for the same thesis. 
NDVI and PRI, as physiological indexes linked to yield [57], highlighted the lowest values in tomatoes treated with $\mathrm{LD}+\mathrm{BC}$, suggesting a better utilization of the readily available nitrogen forms by plants [58], during the crop growth cycle, than the other fertilizers and the untreated control, putatively with a lower impact on nitrate leaching and nitrogen volatilization. However, further studies investigating these physiological and agronomic parameters in different growth stages and under environmental conditions seem to be necessary to corroborate this hypothesis.

While considering the importance of climatic conditions, genotype, soil properties on crop performances, water and nitrogen availability are the main factor affecting yield $[59,60]$ and hence the profitability of the processing tomato production [61,62].

The highest values of FWP and NAE as resulted in LD + BC administration indicated a maximized use of water and nitrogen, in both the trial years. These findings agreed with previous investigations, indicating the positive correlation between marketable yield and water and nutrient use efficiencies in processing tomato production $[49,63]$.

Regarding fruit quality, ${ }^{\circ} \mathrm{Brix}$, a measure of total soluble solids, is a very impacting parameter for tomato canning companies [64] and is often negatively correlated to fruit yield $[65,66]$. Indeed, as shown in the present study, the highest yield as the effect of $\mathrm{LD}+\mathrm{BC}$ application resulted in lower ${ }^{\circ} \mathrm{Brix}$ respect to $B C$ and $L D$ fertilizers separately applied to the plants. Conversely, for the last treatments, lower fruit yield and a higher ${ }^{\circ}$ Brix than $\mathrm{LD}+\mathrm{BC}$ administration were noticed. Nonetheless, the highest yield recorded for $\mathrm{LD}+\mathrm{BC}$ treatments allowed to achieve the highest values of Brix $\mathrm{tha}^{-1}$, in both assessed years, resulting in the high profitability of processing tomato production. Indeed, tomato paste is produced and sold based on its total soluble solids content, thus, the total soluble solids dictate the factory yield [63].

BER and Bostwick viscosity are other two important quality parameters in processing tomatoes. The highest values of BER found in LD-fertilized plants, both 2017 and 2018, can be due to the high concentration of the ammonia and ammonium nitrogen forms contained in the LD [67,68]. According to this hypothesis, recently Hagassou et al. [69], reported an increment of BER incidences on tomato fruits when fertilizers containing ammonium nitrogen were applied. Among the fertilizers studied in this research, PD displayed the lowest values of fruit affected by BER, and LD + BC combination was also interesting because it did not increase this fruit physiological disorder. With regards to BER, more studies are necessary to clarify the effects of the investigated fertilizers on soil calcium availability as well as plant calcium uptake and its translocation to fruit. Finally, as expected high values of ${ }^{\circ}$ Brix resulted in low values of Bostwick viscosity, as also suggested by May and Gonzales [70]. For fruit quality attributes, a usefully improved of Bostwick viscosity was found applying LD fertilizer alone or in combination with $\mathrm{BC}$ and these results can be related to better plant nutrition during fruit ripening. On the other hand, no information is available about the effect of the adopted fertilizers on the Bostwick index.

The highest yield of $\mathrm{LD}+\mathrm{BC}$ thesis also resulted in a worsening of the $\mathrm{pH}$ of tomato juice. An inverse correlation between yield and $\mathrm{pH}$ was already reported by Parisi et al. [71] studying nitrogen fertilization in processing tomato grown in Southern Italy.

Our results demonstrated that the organic fertilizers assessed in our work improved different fruit quality attributes of processing tomato in agreement with the results reported by Asami et al. [72], on strawberry grown under the OFS.

Finally, an assessment of the carbon footprint and the economic impact of the fertilizers should be investigated in the next studies.

\section{Conclusions}

Fertilizers assessed in our work improved marketable yield and fruit quality of processing tomato cultivated in Northern Italy under the OFS. The highest values of total and marketable yields were obtained with $\mathrm{LD}+\mathrm{BC}$ combination and these results were related to the highest plant growth and fertility in terms of fruit number per plant, fruit weight, main stem length, aboveground biomass, FWP 
and NAE. Moreover, LD + BC improved two important fruit quality parameters like Brix $\mathrm{tha}^{-1}$ and Bostwick viscosity thus ensuring an improved fruit quality for tomato canning companies. Furthermore, $\mathrm{LD}+\mathrm{BC}$ fertilization showed the lowest values of NDVI and PRI, suggesting more rapid nitrogen assimilation during the crop growth cycle and early plant senescence at fruit maturity, ultimately resulting in facilitated mechanical harvesting. Hence, our results can be considered in future research aiming to improve fruit yield and quality in other crops grown under the OFS, as well as for new precision agronomic strategies and facing the environmental uncertainties of climate change. However, further studies are needed to study the effects of the available macro- and micronutrients of the fertilizers assessed in the present study, as well as the presence of substances and microorganisms able to stimulate plant growth.

Author Contributions: D.R. and F.C.; methodology, D.R., F.C., G.B.; investigation, D.R., F.C., B.P., M.P., G.A., S.P.; resources, D.R. and E.F.; data curation, D.R., B.P., M.P.; writing-original draft preparation, D.R. and F.C.; writing-review and editing, D.R., F.C., E.F., M.P., B.P., G.A., S.P., G.B.; supervision, D.R.; funding acquisition, D.R. and E.F. All authors have read and agreed to the published version of the manuscript.

Funding: This research was partially funded by the EU-ERDF, Emilia-Romagna Regional Operational Programme POR-FESR 2014/2020, project GENBACCA (PG/2015/728079), and by BIOPRIME (Italian MiPAF project code 1.10.05).

Acknowledgments: We wish to thank Andrea Ferretti (La Collina, Reggio Emilia, RE, Italy) for providing the field trials and Massimo Zaghi (CAT, Correggio, RE, Italy) for providing digestate and pellets. The authors thanks Mariangela Cucino and Giulio Zaccagnini for their collaboration.

Conflicts of Interest: The authors declare no conflict of interest.

\section{References}

1. World Processing Tomato Council (WPTC). 2019. Available online: https://www.wptc.to (accessed on 8 December 2019).

2. Eyhorn, F.; Muller, A.; Reganold, J.P.; Frison, E.; Herren, H.R.; Luttikholt, L.; Mueller, A.; Sanders, J.; El-Hage Scialabba, N.; Seufert, V.; et al. Sustainability in global agriculture driven by organic farming. Nature 2019, 2, 253-255. [CrossRef]

3. Reganold, J.P.; Wachter, J.M. Organic agriculture in the twenty-first century. Nat. Plants 2016, 2, 1-8. [CrossRef] [PubMed]

4. Tuomisto, H.L.; Hodge, I.D.; Riordan, P.; Macdonald, D.W. Does organic farming reduce environmental impacts? A meta-analysis of European research. J. Environ. Manag. 2012, 112, 309-320. [CrossRef] [PubMed]

5. Pimentel, D.; Hepperly, P.; Hanson, J.; Douds, D.; Seidel, R. Environmental, energetic, and economic comparisons of organic and conventional farming systems. BioScience 2005, 55, 573-582. [CrossRef]

6. Gomiero, T.; Pimentel, D.; Paoletti, M.G. nvironmental impact of different agricultural management practices: Conventional vs. organic agriculture. Crit. Rev. Plant Sci. 2011, 30, 95-124. [CrossRef]

7. Crow der, D.W.; Northfield, T.D.; Strand, M.R.; Snyder, W.E. Organic agriculture promotes evenness and natural pest control. Nature 2010, 466, 109-112. [CrossRef]

8. Lynch, D.H.; Halberg, N.; Bhatta, G.D. Environmental impacts of organic agriculture in temperate regions. CAB Rev. 2012, 7, 1-17. [CrossRef]

9. Lee, K.S.; Choe, Y.C.; Park, S.H. Measuring the environmental effects of organic farming: A meta-analysis of structural variables in empirical research. J. Environ. Manag. 2015, 162, 263-274. [CrossRef]

10. Mondelaers, K.; Aertsens, J.; Van Huylenbroeck, G. A meta-analysis of the differences in environmental impacts between organic and conventional farming. Br. Food J. 2009, 111, 1098-1119. [CrossRef]

11. Seufert, V.; Ramankutty, N.; Foley, J.A. Comparing the yields of organic and conventional agriculture. Nature 2012, 485, 229. [CrossRef]

12. De Ponti, T.; Rijk, B.; van Ittersum, M.K. The crop yield gap between organic and conventional agriculture. Agric. Syst. 2012, 108, 1-9. [CrossRef]

13. Ronga, D.; Lovelli, S.; Zaccardelli, M.; Perrone, D.; Ulrici, A.; Francia, E.; Milc, J.; Pecchioni, N. Physiological responses of processing tomato in organic and conventional Mediterranean cropping systems. Sci. Hortic. 2015, 190, 161-172. [CrossRef] 
14. Ronga, D.; Zaccardelli, M.; Lovelli, S.; Perrone, D.; Francia, E.; Milc, J.; Ulrici, A.; Pecchioni, N. Biomass production and dry matter partitioning of processing tomato under organic vs. conventional cropping systems in a Mediterranean environment. Sci. Hortic. 2017, 224, 163-170. [CrossRef]

15. Ronga, D.; Gallingani, T.; Zaccardelli, M.; Perrone, D.; Francia, E.; Milc, J.; Pecchioni, N. Carbon footprint and energetic analysis of tomato production in the organic vs. the conventional cropping systems in Southern Italy. J. Clean. Prod. 2019, 220, 836-845. [CrossRef]

16. Riahi, A.; Hdider, C.; Sanaa, M.; Tarchoun, N.; Ben Kheder, M.; Guezal, I. Effect of conventional and organic production systems on the yield and quality of field tomato cultivars grown in Tunisia. J. Sci. Food Agric. 2009, 89, 2275-2282. [CrossRef]

17. Bettiol, W.; Ghini, R.; Galvão, J.A.H.; Siloto, R.C. Organic and conventional tomato cropping systems. Sci. Agric. 2004, 61, 253-259. [CrossRef]

18. Cavigelli, M.A.; Teasdale, J.R.; Conklin, A.E. Long-term agronomic performance of organic and conventional field crops in the mid-Atlantic region. Agrobiol. J. 2008, 100, 785-794. [CrossRef]

19. Barzee, T.J.; Edalati, A.; El-Mashad, H.; Wang, D.; Scow, K.; Zhang, R. Digestate biofertilizers support similar or higher tomato yields and quality than mineral fertilizer in a subsurface drip fertigation system. Front. Sustain. Food Syst. 2019, 3, 58. [CrossRef]

20. Scholberg, J.; McNeal, B.L.; Boote, K.J.; Jones, J.W.; Locascio, S.J.; Olson, S.M. Nitrogen stress effects on growth and nitrogen accumulation by field-grown tomato. Agron. J. 2000, 92, 159-167. [CrossRef]

21. Pulvirenti, A.; Ronga, D.; Zaghi, M.; Tomasselli, A.R.; Mannella, L.; Pecchioni, N. Pelleting is a successful method to eliminate the presence of Clostridium spp. from the digestate of biogas plants. Biomass Bioenerg. 2015, 81, 479-482. [CrossRef]

22. Sapp, M.; Harrison, M.; Hany, U.; Charlton, A.; Thwaites, R. Comparing the effect of digestate and chemical fertilizer on soil bacteria. Appl. Soil Ecol. 2015, 86, 1-9. [CrossRef]

23. Ronga, D.; Pellati, F.; Brighenti, V.; Laudicella, K.; Laviano, L.; Fedailaine, M.; Benvenuti, S.; Pecchioni, N.; Francia, E. Testing the influence of digestate from biogas on growth and volatile compounds of basil (Ocimum basilicum L.) and peppermint (Mentha $\times$ piperita L.) in hydroponics. J. Appl. Res. Med. Aromat. Plants 2018, 11, 18-26. [CrossRef]

24. Ronga, D.; Setti, L.; Salvarani, C.; De Leo, R.; Bedin, E.; Pulvirenti, A.; Milc, J.; Pecchioni, N.; Francia, E. Effects of solid and liquid digestate for hydroponic baby leaf lettuce (Lactuca sativa L.) cultivation. Sci. Hortic. 2019, 244, 172-181. [CrossRef]

25. Ronga, D.; Francia, E.; Allesina, G.; Pedrazzi, S.; Zaccardelli, M.; Pane, C.; Tava, A.; Bignami, C. Valorization of vineyard by-products to obtain composted digestate and biochar suitable for nursery grapevine (Vitis vinifera L.) production. Agronomy 2019, 9, 420. [CrossRef]

26. Šimon, T.; Kunzová, E.; Friedlová, M. The effect of digestate. Cattle slurry and mineral fertilization on the winter wheat yield and soil quality parameters. Plant Soil Environ. 2015, 61, 522-527. [CrossRef]

27. Lehmann, J.; Joesph, S. Biochar for Environmental Management: Science and Technology; Earthscan Ltd.: London, UK, 2009.

28. Palansooriya, K.N.; Ok, Y.S.; Awad, Y.M.; Lee, S.S.; Sung, J.-K.; Koutsospyros, A.; Moon, D.H. Impacts of biochar application on upland agriculture: A review. J. Environ. Manag. 2019, 234, 52-64. [CrossRef]

29. Xu, N.; Tan, G.; Wang, H.; Gai, X. Effect of biochar additions to soil on nitrogenleaching, microbial biomass and bacterial community structure. Eur. J. Soil Biol. 2016, 74, 1-8. [CrossRef]

30. Gao, S.; Hoffman-Krull, K.; DeLuca, T.H. Soil biochemical properties and crop productivity following application of locally produced biochar at organic farms in Waldron Island, WA. Biogeochemistry 2017, 136, 31. [CrossRef]

31. Gonzaga, M.I.S.; Mackowiak, C.; de Almeida, A.Q.; Wisniewski, A., Jr.; de Souza, D.F.; da Silva Lima, I.; de Jesus, A.N. Assessing biochar applications and repeated Brassica juncea L. Production cycles to remediate Cu contaminated soil. Chemosphere 2018, 201, 278-285. [CrossRef]

32. Hol, W.G.; Vestergård, M.; ten Hooven, F.; Duyts, H.; van de Voorde, T.F.; Bezemer, T.M. Transient negative biochar effects on plant growth are strongest after microbial species loss. Soil Biol. Biochem. 2017, 115, 442-451. [CrossRef]

33. USDA NRCS. Keys to Soil Taxonomy, National Cooperative Soil Survey, 10th ed.; USDA NRCS: Madison, WI, USA, 2006. 
34. Hargreaves, G.H.; Samani, Z.A. Reference crop evapotranspiration from tem-perature. Appl. Eng. Agric. 1985, 1, 96-99. [CrossRef]

35. Allen, R.G.; Pereira, L.S.; Raes, D.; Smith, M. Crop Evapotranspiration. Guidelines for Computing Crop Water Requirements FAO Irrigation and Drainage Paper 56; FAO: Rome, Italy, 1998; Paper No. 24 (review).

36. Doorenbos, J.; Pruitt, W.O. Crop Water Requirement; FAO Irrigation and Drainage; FAO: Rome, Italy, 1977.

37. Cabello, M.J.; Castellanos, M.T.; Romojaro, F.; Martinez-Madrid, C.; Ribas, F. Yield and quality of melon grown under different irrigation and nitrogen rates. Agric. Water Manag. 2009, 96, 866-874. [CrossRef]

38. Padilla-Díaz, C.M.; Rodriguez-Dominguez, C.M.; Hernandez-Santana, V.; Perez-Martin, A.; Fernandes, R.D.M.; Montero, A.; García, J.M.; Fernández, J.E. Water status, gas exchange and crop performance in a super high density olive orchard under deficit irrigation scheduled from leaf turgor measurements. Agric. Water Manag. 2018, 202, 241-252. [CrossRef]

39. Ranganna, S. Handbook of Analysis and Quality Control for Fruits and Vegetable Products; Tata McGraw Hill Publishing Company Ltd.: New Delhi, India, 2011.

40. Gomez, K.A.; Gomez, A.A. Statistical Procedures for Agricultural Research; John Wiley \& Sons: New York, NY, USA, 1984.

41. Lovelli, S.; Potenza, G.; Castronuovo, D.; Perniola, M.; Candido, V. Yield, quality and water use efficiency of processing tomatoes produced under different irrigation regimes in Mediterranean environment. Ital. J. Agron. 2017, 12, 17-24. [CrossRef]

42. Clark, M.S.; Horwath, W.R.; Shennan, C.; Scow, K.M.; Lantni, W.T.; Ferris, H. Nitrogen, weeds and water as yield-limiting factors in conventional, low-input, and organic tomato systems. Agric. Ecosyst. Environ. 1999, 73, 257-270. [CrossRef]

43. Muller, A.; Schader, C.; Scialabba, N.E.H.; Brüggemann, J.; Isensee, A.; Erb, K.H.; Smith, P.; Klocke, P.; Leiber, F.; Stolze, M.; et al. Strategies for feeding the world more sustainably with organic agriculture. Nat. Commun. 2017, 8, 1290. [CrossRef]

44. Hempel, C.; Hamm, U. Local and/or organic: A study on consumer preferences for organic food and food from different origins. Int. J. Consum. Stud. 2016, 40, 732-741. [CrossRef]

45. Ronga, D.; Caradonia, F.; Setti, L.; Hagassou, D.; Giaretta Azevedo, C.V.; Milc, J.; Pedrazzi, S.; Allesina, G.; Arru, L.; Francia, E. Effects of innovative biofertilizers on yield of processing tomato cultivated in organic cropping systems in northern Italy. Acta Hortic. 2019, 1233, 129-136. [CrossRef]

46. Bustamante, S.C.; Hartz, T.K. Nitrogen management in organic processing tomato production: Nitrogen sufficiency prediction through early-season soil and plant monitoring. HortScience 2015, 50, 1055-1063. [CrossRef]

47. Stat, I. Available online: http://dati.istat.it/Index.aspx?DataSetCode=DCSP_COLTIVAZIONI (accessed on 8 December 2019).

48. Barrios-Masias, F.H.; Jackson, L.E. California processing tomatoes: Morphological, physiological and phenological traits associated with crop improvement during the last 80 years. Eur. J. Agron. 2014, 53, 45-55. [CrossRef]

49. Ronga, D.; Francia, E.; Rizza, F.; Badeck, F.W.; Caradonia, F.; Montevecchi, G.; Pecchioni, N. Changes in yield components, morphological, physiological and fruit quality traits in processing tomato cultivated in Italy since the 1930's. Sci. Hortic. 2019, 257, 108726. [CrossRef]

50. Grandillo, S.; Zamir, D.; Tanksley, S.D. Genetic improvement of processing tomatoes: A 20 years perspective. Euphytica 1999, 110, 85-97. [CrossRef]

51. Higashide, T.; Heuvelink, E. Physiological and morphological changes over the past 50 years in yield components in Tomato. J. Am. Soc. Hortic. Sci. 2009, 134, 460-465. [CrossRef]

52. Laird, D.; Fleming, P.; Wang, B.; Horton, R.; Karlen, D. Biochar impact on nutrient leaching from a Midwestern agricultural soil. Geoderma 2010, 158, 436-442. [CrossRef]

53. Sun, F.; Lu, S. Biochars improve aggregate stability, water retention, and pore-space properties of clayey soil. J. Plant Nutr. 2014, 177, 26-33. [CrossRef]

54. Scaglia, B.; Pognani, M.; Adani, F. The anaerobic digestion process capability to produce biostimulant: The case study of the dissolved organic matter (DOM) vs. auxin-like property. Sci. Total Environ. 2017, 589, $36-45$. [CrossRef] 
55. Fischer, R.A.; Rees, D.; Sayre, K.D.; Lu, Z.M.; Condon, A.G.; Saavedra, A.L. Wheat yield progress associated with higher stomatal conductance and photosynthetic rate, and cooler canopies. Crop Sci. 1998, 38, 1467-1475. [CrossRef]

56. Cerovic, Z.G.; Masdoumier, G.; Ghozlen, N.B.; Latouche, G. A new optical leaf-clip meter for simultaneous non-destructive assessment of leaf chlorophyll and epidermal flavonoids. Physiol. Plant. 2012, 146, 251-260. [CrossRef]

57. Fortes, R.; Prieto, M.H.; Terrón, J.M.; Blanco, J.; Millán, S.; Campillo, C. Using apparent electric conductivity and NDVI measurements for yield estimation of processing tomato crop. Trans. ASABE 2014, 57, 827-835.

58. Möller, K.; Müller, T. Effects of anaerobic digestion on digestate nutrient availability and crop growth: A review. Eng. Life Sci. 2012, 12, 242-257. [CrossRef]

59. Cammarano, D.; Ceccarelli, S.; Grando, S.; Romagosa, I.; Benbelkacem, A.; Akar, T.; Ronga, D. The impact of climate change on barley yield in the Mediterranean basin. Eur. J. Agron. 2019, 106, 1-11. [CrossRef]

60. Cammarano, D.; Hawes, C.; Squire, G.; Holland, J.; Rivington, M.; Murgia, T.; Ronga, D. Rainfall and temperature impacts on barley (Hordeum vulgare L.) yield and malting quality in Scotland. Field Crop. Res. 2019, 241, 107559. [CrossRef]

61. Giuliani, M.M.; Gatta, G.; Nardella, E.; Tarantino, E. Water saving strategies assessment on processing tomato cultivated in Mediterranean region. Ital. J. Agron. 2016, 11, 69-76. [CrossRef]

62. Farneselli, M.; Benincasa, P.; Tosti, G.; Pace, R.; Tei, F.; Guiducci, M. Nine-year results on maize and processing tomato cultivation in an organic and in a conventional low input cropping system. Ital. J. Agron. 2013, 8, e2. [CrossRef]

63. Di Cesare, L.F.; Migliori, C.; Viscardi, D.; Parisi, M. Quality of tomato fertilized with nitrogen and phosphorous. Ital. J. Food Sci. 2010, 22, 186-191.

64. Ronga, D.; Parisi, M.; Pentangelo, A.; Mori, M.; Di Mola, I. Effects of nitrogen management on biomass production and dry matter distribution of processing tomato cropped in southern Italy. Agronomy 2019, 9, 855. [CrossRef]

65. Fulton, T.M.; Beck-Bunn, T.; Emmatty, D.; Eshed, Y.; Lopez, J.; Petiard, V.; Uhlig, J.; Zamir, D.; Tanksley, S.D. QTL analysis of an advanced backcross of Lycopersicon peruvianum to the cultivated tomato and comparisons with QTLs found in other wild species. Theor. Appl. Genet. 1997, 95, 881-894. [CrossRef]

66. Schauer, N.; Semel, Y.; Roessner, U.; Gur, A.; Balbo, I.; Carrari, F.; Pleban, T.; Perez-Melis, A.; Bruedigam, C.; Kopka, J.; et al. Comprehensive metabolic profiling and phenotyping of interspecific introgression lines for tomato improvement. Nat. Biotechnol. 2006, 24, 447-454. [CrossRef]

67. Xia, A.; Murphy, J.D. Microalgal cultivation in treating liquid digestate from biogas systems. Trends Biotechnol. 2016, 34, 264-275. [CrossRef]

68. Törnwall, E.; Pettersson, H.; Thorin, E.; Schwede, S. Post-treatment of biogas digestate-An evaluation of ammonium recovery, energy use and sanitation. Energy Procedia 2017, 142, 957-963. [CrossRef]

69. Hagassou, D.; Francia, E.; Ronga, D.; Buti, M. Blossom end-rot in tomato (Solanum lycopersicum L.): A multidisciplinary overview of inducing factors and control strategies. Sci. Hortic. 2019, 249, 49-58. [CrossRef]

70. May, D.M.; Gonzales, J. Irrigation and nitrogen management as they affect fruit quality and yield of processing tomatoes. In Proceedings of the Acta Horticulturae, V International Symposium on the Processing Tomato, Sorrento (SA), Italy, 23-27 November 1993; Volume 376, pp. 227-234.

71. Parisi, M.; Giordano, I.; Pentangelo, A.; D'Onofrio, B.; Villari, G. Effects of different levels of nitrogen fertilization on yield and fruit quality in processing tomato. Acta Hortic. 2006, 700, 129-132. [CrossRef]

72. Asami, D.K.; Hong, Y.J.; Barrett, D.M.; Mitchell, A.E. Comparison of the total phenolic and ascorbic acid content of freeze-dried and air-dried marionberry, strawberry, and corn grown using conventional, organic, and sustainable agricultural practices. J. Agric. Food Chem. 2003, 51, 1237-1241. [CrossRef] [PubMed]

(C) 2020 by the authors. Licensee MDPI, Basel, Switzerland. This article is an open access article distributed under the terms and conditions of the Creative Commons Attribution (CC BY) license (http://creativecommons.org/licenses/by/4.0/). 